\title{
POTENTIAL GUT ADHERENT PROBIOTIC BACTERIA ISOLATED FROM ROHU, LABEO ROHITA (ACTINOPTERYGII: CYPRINIFORMES: CYPRINIDAE): CHARACTERISATION, EXO-ENZYME PRODUCTION, PATHOGEN INHIBITION, CELL SURFACE HYDROPHOBICITY, AND BIO-FILM FORMATION
}

\author{
Dipanjan DUTTA ${ }^{1,2}$, Sudeshna BANERJEE ${ }^{1}$, Anjan MUKHERJEE ${ }^{1}$, and Koushik GHOSH ${ }^{*}$ \\ ${ }^{1}$ Aquaculture Laboratory, Department of Zoology, University of Burdwan, Golapbag, Burdwan, West Bengal, India \\ ${ }^{2}$ Post Graduate Department of Zoology, Hooghly Mohsin College, Chinsurah, West Bengal, India
}

Dutta D., Banerjee S., Mukherjee A., Ghosh K. 2018. Potential gut adherent probiotic bacteria isolated from rohu, Labeo rohita (Actinopterygii: Cypriniformes: Cyprinidae): Characterisation, exo-enzyme production, pathogen inhibition, cell surface hydrophobicity, and bio-film formation. Acta Ichthyol. Piscat. 48 (3): 221-233.

\begin{abstract}
Background. Previous reports emphasized exo-enzyme production and pathogen inhibition as major criteria to select putative probiotics in carps. However, adhesion ability to the gut epithelium could be one of the decisive factors. The presently reported study was aimed to determine the probiotic potential of autochthonous bacteria isolated from gastrointestinal (GI) tract of rohu, Labeo rohita (Hamilton, 1822). Apart from characterization of functional probiotic attributes and bio-safety, the presently reported study utilized in vitro model system for preliminary selection of potentially adherent strains.
\end{abstract}

Materials and methods. Altogether, 126 exo-enzyme producing bacteria were isolated from the proximal (PI) and distal (DI) segment of the GI tract and evaluated for enzyme-producing ability (viz., amylase, protease, lipase, cellulase, phytase, xylanase). Pathogen inhibition was tested by cross-streaking and double-layer method. Based on the cumulative results, isolates LR3H1A and LR3F3P were selected and identified by phenotypic and 16S rRNA partial gene sequence analyses. Both the strains were tested for their ability to grow in fish mucus, tolerance to fish bile, and bio-safety. Cell surface characteristics of the strains were analysed by aggregation assays and biofilm forming ability was determined through adherence to glass and polystyrene surfaces.

Results. Seven strains (PI-4, DI-3) were primarily selected as efficient exo-enzyme producers, of which 3 strains (PI-2, DI-1) were found to be antagonistic against $\geq 1$ of the 6 tested fish pathogens. Partial characterization of the cell-free supernatant revealed that the antagonistic compound was proteinaceous, showing its maximum efficacy at $30^{\circ} \mathrm{C}$ and $\mathrm{pH}$ 7. Isolates LR3H1A and LR3F3P were identified as Bacillus subtilis subsp. spizizenii (KF623286) and Bacillus tequilensis (KF623287), respectively. Both the strains grew well in fish mucus, tolerated diluted bile juice, and showed evidence of bio-safety. Both the strains were categorized as a moderate bio-film producer, although LR3F3P was noticed to possess stronger cell surface hydrophobicity, auto-aggregation and co-aggregation capacity than LR3H1A.

Conclusion. Owing to better colonization potential, presently reported study indicated B. tequilensis LR3F3P as a putative probiotic for feed application.

Keywords: gut bacteria, Indian major carp, Bacillus, exo-enzyme, bacteriocin, fish pathogen

\section{INTRODUCTION}

Increasing feed efficiency and disease prevention is the major thrust in the commercial fish farming industry. The gastrointestinal (GI) tract in fish is a multifunctional organ, where the complex microbial community interacts with the external as well as internal environment influencing health and disease (Ringø et al. 2016). Several studies have described that the gut microbiota in fish has specific metabolic, trophic, and protective functions (e.g., Yaghobi et al. 2014, Liu et al. 2016). Comprehensive investigations during the last two decades have the enzymatic potential of the commensal microorganisms within the GI tract of fish (Ray et al. 2012, Wang et al. 2018). Consequently, the use of enzyme-producing gut microbiota as potential probiotics has been suggested to improve feed utilization efficiency of fish (Ray et al. 2012, Hai 2015). In addition, the gut microbiota has been shown to possess antagonistic activity against several fish pathogens through the production of diverse products viz., organic acids, hydrogen peroxide, lysozyme, siderophores, and 
bacteriocins (Burr et al 2005, Denev et al. 2009, Sugita et al. 2012). Nevertheless, several countries imposed restrictions on antibiotic usage for aquaculture production due to the emergence of antibiotic-resistant strains (Tang et al. 2017). Therefore, the use of pathogen inhibitory gut bacteria as probiotics has been proposed as alternative biological control agents (Kesarcodi-Watson et al. 2008). Apart from these, the resident gut microbiota confers other benefits that might include metabolism of nutrients, synthesis of bio-molecules (e.g., vitamins, amino acids), immunomodulation, adherence and colonization of pathogenic agents (Burr et al 2005, Denev et al. 2009, Romero et al. 2014). Although a single organism may not fulfil all of these characteristics, the candidates that accomplish more of these characteristics should be considered as appropriate probiotics (Hai 2015).

The development of suitable probiotics requires empirical and fundamental research to improve our understanding of the functional role that individual microbes might play, as well as on their viability and bio-safety. As fish interact with a varied range of microorganisms with diverse functionality, screening of probiotics for particular fish species appears to be a vital role to make them species specific (Hai 2015). Generally, probiotics used in finfish aquaculture are applied either as a feed supplement or as a water additive (Cruz et al. 2012, Gupta et al. 2016). Selecting appropriate method of administration might ensure delivery of the putative probiotics to the fish at the adequate number. Adherence in the intestine of the host is required for the probiotic strains to exert a beneficial health effect. Thus, the adhesion ability to the intestinal epithelium has been suggested as one of the main criteria for selecting probiotic strains to be applied through both, feed or water additive ( $\mathrm{Li}$ et al. 2018). Autoaggregation of probiotic strains appeared to be necessary for adhesion to intestinal epithelial cells, and coaggregation abilities may form a barrier that prevents colonization by pathogenic microorganisms (Del Re et al. 2000). On the other hand, organisms capable of forming bio-film could ideally be applied as water additives. Cell surface hydrophobicity influences the attachment of microbial cells to a surface and thereby formation of bacteria bio-film. Difficulties involved in studying bacterial adhesion in vivo, have led to the development of in vitro model systems for the preliminary selection of potentially adherent strains (Kimoto et al. 1999).

Among the Indian major carps (IMC), rohu, Labeo rohita (Hamilton, 1822), constitutes the most important component of the carp polyculture practice throughout Asia contributing nearly 1.7 million tons of annual production (Anonymous 2018). Rapid growth, compatibility with other fishes, acceptance of artificial diet, good quality of flesh, and consumer preference made this species ideal for the aquaculture industry. Therefore, development of suitable probiotic strains for rohu holds promise to sustain aquaculture production of this tropical freshwater fish. In this context, the presently reported study aimed at characterization of gut bacteria in rohu in order to assess their potential as probiotics. Apart from functional characterization contended with extracellular-enzyme production and antagonism against 1 or more pathogenic bacteria, in vitro probiotic properties, viz., growth in gut mucus, bile tolerance, cell surface hydrophobicity and biofilm formation abilities of the isolates were investigated. Further, partial characterization of the antagonistic compound was carried out to substantiate the pathogen inhibitory ability of the selected gut bacteria.

\section{MATERIALS AND METHODS}

Sample collection, processing and isolation of gut bacteria. Nine live specimens of rohu (mean weight 250 $\pm 13.24 \mathrm{~g}$ ) having no external disease symptoms were collected from three different carp polyculture ponds located in and around Burdwan $\left(23^{\circ} 24^{\prime} \mathrm{N}, 87^{\circ} 86^{\prime} \mathrm{E}\right)$, West Bengal, India. The fish were deprived of food for $48 \mathrm{~h}$ in order to clear their GI tracts from traces of any undigested food or faecal matter and to eliminate most of the allochthonous bacteria associated with digesta (Ghosh et al. 2010). The fish were anaesthetized by applying $0.03 \%$ tricaine methanesulfonate (MS-222; Sigma Aldrich, USA). The GI tracts were removed aseptically, divided into proximal (PI; oesophagus, intestinal bulb and $1 / 3$ of the intestine) and distal (DI; posterior intestine) parts and subsequently processed as described elsewhere (Ghosh et al. 2010). Portions of the GI tracts from three fish collected from each pond were pooled together region-wise and homogenized with sterilized chilled phosphate buffered saline $(0.9 \%$, $\mathrm{w} / \mathrm{v}$; $\mathrm{pH}$ 7.0) for using as inoculums in each replicate. Homogenates were serially diluted $(1: 10)$ and plated onto sterilized soybean casein digest (Tryptone Soya Agar, TSA; HiMedia, Mumbai, India) plates to determine the autochthonous culturable heterotrophic aerobic/facultative anaerobic bacteria population. Amylase, protease, lipase, cellulase, xylanase, and phytase producing bacteria were isolated following enrichment culture technique using starch (ST), peptone-gelatine (PG), tributyrin (TB), carboxymethylcellulose (CMC), xylan (XY), and modified phytase screening (MPS) plates, respectively. After incubation $\left(30^{\circ} \mathrm{C}, 48 \mathrm{~h}\right)$, bacteria colonies which appeared were resolved by dilution plate count method and expressed as log viable counts $\mathrm{g}^{-1}$ GI tract (LVC) (Mandal and Ghosh 2013). The pure culture of the isolates was maintained on slants in a refrigerator $\left(4^{\circ} \mathrm{C}\right)$ for further study.

Determination of extracellular enzyme production: Qualitative and quantitative assay. Bacteria isolates were evaluated for exo-enzyme producing capacities on the selective media plates containing suitable substrates. Qualitative assay of amylase and protease were performed following the methods described by Jacobs and Gerstein (1960). Qualitative determination of lipase, cellulase, phytase, and xylanase activities were carried out following Sangiliyandi and Gunasekaran (1996), Teather and Wood (1982), Howson and Davis (1983), and Ninawe et al. (2006), respectively. Detail descriptions of the methods were presented in Dutta and Ghosh (2015). Appearance of halo around the colony (diameter in $\mathrm{mm}$ ) due to utilization of substrates by extracellular enzyme activity was presented as scores; 0, nil (no halo); 1, low (6-10 mm 
halo); 2, moderate (11-20 mm halo); 3, good (21-30 mm halo); 4, high (31-39 mm halo); 5, very high ( $\geq 40 \mathrm{~mm}$ halo) (Das et al. 2014, Dutta and Ghosh 2015).

Proficient extracellular enzyme producing isolates (qualitative score $\geq 20$ ) were selected for quantitative assay. Quantitative assays for the production of amylase, cellulase, protease, and lipase were performed following the methods described by Bernfeld (1955), Denison and Koehn (1977), Walter (1984), and Bier (1955), respectively. Quantitative assay of xylanase and phytase activities were measured following Bailey et al. (1992) and Yanke et al. (1999), respectively. Quantitative enzyme activities were expressed as units ( $\mathrm{U}=$ unit weight of the breakdown product liberated $\mathrm{mL}^{-1}$ of enzyme extract $\mathrm{min}^{-1}$ ).

Determination of pathogen inhibitory activity and partial characterization of bacteriocin. Five fish pathogenic strains Aeromonas hydrophila MTCC-1739 (AH), Aeromonas salmonicida MTCC-1945 (AS), Pseudomonas fluorescens MTCC-103 (PF), Pseudomonas putida MTCC-1072 (PP), and Bacillus mycoides MTCC7538 (BM) were acquired from the Microbial Type Culture Collection, Chandigarh, India. In addition, Aeromonas veronii (AV) isolated from diseased 'Catla catla', Labeo catla (Hamilton, 1822), and established as a pathogen in a previous study (Mukherjee and Ghosh 2016), was used.

The promising enzyme-producing isolates were tested for pathogen inhibitory activity against 6 fish pathogens primarily by cross-streaking method (Alippi and Reynaldi 2006) and the strains showing antagonistic activity against $\geq 1$ studied fish pathogens were further confirmed by the double-layer method (Dopazo et al. 1988) with minor modification. A clear zone of inhibition (halo) around growth of the selected gut bacteria indicated antibacterial activity and the halo (diameter in excess of colony growth) around the colony was presented as follows; +, low (6-10 $\mathrm{mm})$; ++ , moderate $(11-20 \mathrm{~mm}) ;+++$, high $(21-25 \mathrm{~mm})$; ++++ , very high $(\geq 26 \mathrm{~mm})$.

The bacteriocin-like compound produced by the two promising isolates (LR3H1A and LR3F3P) was partially characterized after Giri et al. (2012) and Mukherjee et al. (2016) with minor modification. Following growth in TSB $\left(30^{\circ} \mathrm{C}, 48 \mathrm{~h}\right)$, cell-free supernatant (CFS) was collected, filter sterilized $(0.22 \mu \mathrm{m}$; HiMedia, Mumbai, India), and stored at $-80^{\circ} \mathrm{C}$ for further use as crude bacteriocin (CB). The $\mathrm{CB}$ obtained from LR3H1A and LR3F3P were subjected to heat treatment, $\mathrm{pH}$ alteration, and enzyme treatment ( $\alpha$-amylase, trypsin, proteinase $\mathrm{K}$ and lysozyme; $1.0 \mathrm{mg} \mathrm{mL}^{-1}$ ), following which the treated $\mathrm{CB}$ were studied for inhibition of $\mathrm{AH}$ by agar well diffusion method. The CB sample without treatment was served as control in each case.

Morphological, physiological and biochemical characterization of the bacteria isolates. Two selected isolates (LR3H1A and LR3F3P) were subjected to morphological, physiological, and various biochemical tests following standard methods described in the Bergey's Manual of Systematic Bacteriology (Bergey and Holt 1994). Identification of the isolates by $16 \mathrm{~S}$ rRNA partial gene sequence analysis. LR3H1A and LR3F3P were further studied by $16 \mathrm{~S}$ rRNA partial gene sequence analyses following the methods described in Dutta et al. (2015). The 16S rRNA gene fragments were amplified by polymerase chain reaction (PCR) using universal primers, viz. 27f (5'-AGAGTTTGATCCTGGCTCAG-3') and 1492r (5'-GGTTACCTTGTTACGACTT-3') (Lane 1991). Sequencing products were determined on an automated DNA sequencer (Applied BioSystems 3730XL, USA), edited with the BioEdit Sequence Alignment Editor (Version 7.2.5), aligned and analysed to find out the closest homolog using National Centre for Biotechnology Information (NCBI) GenBank and Ribosomal Database Project (RDP) databases. Sequences were deposited to the NCBI GenBank and accession numbers were obtained. A phylogenetic tree was constructed using MEGA 7 software following the Minimum Evolution method.

Ability to tolerate gastrointestinal condition. The two selected bacteria, LR3H1A and LR3F3P were assayed for their ability to grow in fish mucus and tolerance toward diluted bile juice following the method described by Dutta and Ghosh (2015).

Cell surface hydrophobicity assays. A total of five assays were performed:

Spontaneous aggregation assay. An overnight grown broth culture of LR3H1A and LR3F3P in TSB was placed on a clean glass slide and rotated manually. Clumping of cells inferred a positive result, whereas a smooth turbid suspension indicated a negative result (Mattos-Guaraldi et al. 1999).

Salt aggregation assay. Salt aggregation assay was performed after Krepsky et al. (2003) with slight modification. Different grades of ammonium sulphate $(0.007 \mathrm{M}$ to $4 \mathrm{M})$ were mixed with a suspension of LR3H1A and LR3F3P $(100 \mu \mathrm{L})$ in a watch glass. The lowest grade of ammonium sulphate giving visible bacterial clumping was scored as salt aggregation index. Bacterial suspension with a salt aggregation index $<2 \mathrm{M}$ was considered as positive.

Auto-aggregation assay. Auto-aggregation assay was performed according to Kos et al. (2003) with minor modifications. The cells of overnight grown broth cultures of LR3H1A and LR3F3P (resuspended in PBS) were mixed using a vortex $(10 \mathrm{~s})$ and incubated $(5 \mathrm{~h})$ at $25^{\circ} \mathrm{C}$. The absorbance $\left(A_{600}\right)$ was recorded for a period of $4 \mathrm{~h}$ at an interval of $1 \mathrm{~h}$. The autoaggregation (AA; \%) ability was expressed as follows

$$
\mathrm{AA}=1-100 \cdot\left(A_{t} \cdot A_{0}^{-1}\right)
$$

where, $A_{t}$ represents the absorbance at time $t=1,2,3$, and $4 \mathrm{~h}$, and $A_{0}$ represents the absorbance at $t=0$.

Co-aggregation assay. Co-aggregation assays were performed according to Jena et al. (2013) with slight alterations. Equal volume $(1: 1)$ of each probiotic and pathogenic suspension (AS, PF, PP, BM, AH) were thoroughly mixed using a vortex (10 s). The tubes were incubated $(5 \mathrm{~h})$ at $25^{\circ} \mathrm{C}$. The co-aggregation (CA; \%) ability was expressed as follows

$$
\mathrm{CA}=100 \cdot\left(A_{0}-A_{t}\right) \cdot A_{0}^{-1}
$$


where, $A_{0}$ represents $\mathrm{OD}_{600}$ of a bacterial mixture at $t=0$, and $A_{t}$ represents the $\mathrm{OD}_{600}$ of a bacterial mixture after 5 $\mathrm{h}$ of incubation.

Microbial adherence to hydrocarbon (MATH). MATH was performed according to Klayraung et al. (2008) with modifications. Solvents used in the present study were n-hexadecane (apolar, n-alkane), xylene (apolar), chloroform (monopolar, Lewis-acid), and ethyl acetate (monopolar, Lewis-base). Broth cultures of LR3H1A and LR3F3P (resuspended in PBS) were grown overnight and $\mathrm{OD}_{600}$ was measured $\left(A_{1}\right)$. Respective solvents $(1 \mathrm{~mL})$ were added separately to each cell suspension, incubated at $30^{\circ} \mathrm{C}$ for $30 \mathrm{~min}$ and $\mathrm{OD}_{600}$ measured against a solventextracted PBS blank $\left(A_{2}\right)$. Percentage of adhesion $\left(A_{\mathrm{dhs}} ; \%\right)$ was expressed as follows

$$
A_{\mathrm{dhs}}=100 \cdot\left(1-A_{2} \cdot A_{1}^{-1}\right)
$$

Ability to form bio-film. Two assays were performed:

Cell adherence to glass and polystyrene surfaces. Preliminary measurement of cell adherence to glass and polystyrene tubes were compared for both strains. Broth cultures of LR3H1A and LR3F3P $\left(10^{8} \mathrm{CFU} \mathrm{mL}{ }^{-1}\right)$ were incubated overnight at $30^{\circ} \mathrm{C}$ under static condition in glass and polystyrene tubes $(5 \mathrm{~mL})$. $\mathrm{OD}_{600}$ of the homogeneously mixed culture was measured $(A)$ in both the tubes. The culture was centrifuged at $5000 \mathrm{~g}$ for $15 \mathrm{~min}$, the supernatant was collected and $\mathrm{OD}_{600}$ was measured $\left(A_{0}\right)$. The process was repeated for three days by inoculating fresh broth with decanted supernatant. Percentage of adhesion $\left(A_{\mathrm{dhr}} ; \%\right)$ was expressed as follows

$$
A_{\mathrm{dhr}}=100 \cdot\left(A-A_{0} \cdot A^{-1}\right)
$$

Semi-quantitative adherence assay. Bio-film production by LR3H1A and LR3F3P was determined using a semiquantitative adherence assay on polystyrene made 96-well tissue culture plates following Chaieb et al. (2007). OD of the adherent and stained bacteria were measured. $\mathrm{OD}_{570}$ $<0.1$ was noted as non bio-film producer and $\mathrm{OD}_{570}>1.0$ was considered as strong bio-film producer.

Safety evaluation. The strains LR3H1A and LR3F3P were injected intra-intraperitoneally into rohu fingerlings (20 for each strain; mean weight: $16.5 \pm 1.25 \mathrm{~g}$ ) and was observed for mortality or onset of disease symptoms (Dutta and Ghosh 2015).

Statistical analysis. Statistical analyses of the quantitative enzyme activity, hydrophobicity assays, and partial characterization of bacteriocin were performed by the one-way analysis of variance (ANOVA) followed by Tukey's test according to Zar (2010) using SPSS Version 19 software (Gray and Kinnear 2011).

\section{RESULTS}

Isolation of gut bacteria and determination of extracellular enzyme-producing capacity. Amylase, protease, lipase, cellulase, phytase, and xylanase producing autochthonous bacteria populations were detected in the proximal (PI) and distal (DI) segments of the GI tract of rohu
(Fig. 1). Heterotrophic and diverse extracellular enzymeproducing bacterial populations were predominantly high in the DI region. While considering different extracellular enzyme-producing bacteria on a comparative scale, the occurrence of amylolytic bacteria was the highest ( $\mathrm{LVC}=$ $5.65)$ followed by lipolytic bacteria $(\mathrm{LVC}=5.34)$, both in the DI segment; whereas, xylan-degrading bacteria populations were the lowest in the PI and DI. Seven extracellular enzyme-producing strains (4 from PI and 3 from DI) were primarily selected on account of qualitative enzyme activity data presented as scores (Table 1), maximum and minimum scores being 28 and 20, respectively. Further, results of the quantitative enzyme assay revealed significant differences in the enzyme activities among the primarily selected bacterial isolates (Table 2).

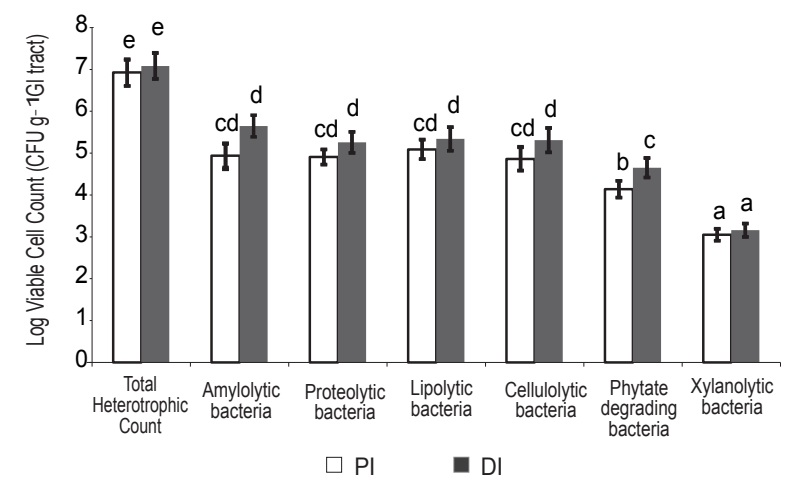

Fig. 1. Log viable counts ( $\mathrm{LVC} \mathrm{g}^{-1}$ GI tract) of adherent bacteria isolated from the proximal intestine (PI) and distal intestine (DI) of rohu, Labeo rohita; data are expressed as mean \pm standard deviation $(n=3), P<0.05$

The highest values for amylolytic $(300.60 \pm 6.04 \mathrm{U})$, proteolytic $(82.38 \pm 2.14 \mathrm{U})$ and phytase $(378.51 \pm 6.22$ U) activities were recorded by strain LR3F3P. While, strain LR3H1A revealed maximum cellulase (72.41 \pm $2.31 \mathrm{U})$, xylanase $(33.68 \pm 1.21 \mathrm{U})$ and lipase $(5.93 \pm 0.28$ $\mathrm{U})$ activities. Overall examinations of the six different extracellular enzyme activities revealed that strains LR3H1A and LR3F3P (qualitative activity score was 28 and 27 , respectively) were the most efficient among the 7 primarily selected bacteria strains.

Determination of antagonistic activity against pathogenic bacteria. To verify pathogen inhibitory activity, the primarily selected 7 extracellular enzymeproducing bacterial isolates were further screened against 6 fish pathogens. Out of the 7 isolates, 3 strains (2 from PI and 1 from DI) inhibited at least one of the tested fish pathogens through cross-streaking method. None of the exoenzyme-producing gut isolates was antagonistic against Bacillus mycoides. Pathogen inhibitory activity of these 3 isolates was further assessed by double layer method and the zone of inhibition (halo) produced by the gut isolates were depicted in Table 3 . In consequence of the maximum extracellular enzyme-producing capacities; strains LR3H1A and LR3F3P were antagonistic against 3 out of the 6 tested fish pathogens. 
Partial characterization of bacteriocin-like compound. inactivated at temperatures above $90^{\circ} \mathrm{C}$. The antibacterial The effect of different treatments on the inhibitory activity activity was lost when the antagonistic compound was of the antagonistic compound produced by LR3H1A treated with proteolytic enzymes (proteinase $\mathrm{K}$ and and LR3F3P against Aeromonas hydrophila MTCC- trypsin), however, remained active under the action of 1739 has been depicted in Fig. 2. Inhibitory activity of lysozyme and $\alpha$-amylase. Therefore, the study revealed the antagonistic compound reduced significantly $(P<$ that the antagonistic compound was proteinaceous in $0.05)$ with increasing temperature and was completely nature and bacteriocin like. The bacteriocin-like compound

Table 1

Qualitative assay of the enzyme activity (presented as scores*) by gut bacteria isolated from the gut of rohu, Labeo rohita

\begin{tabular}{|c|c|c|c|c|c|c|c|}
\hline \multicolumn{8}{|c|}{ Enzyme activity [score] } \\
\hline Strain & Amylase $^{1}$ & Protease $^{2}$ & Lipase $^{3}$ & Cellulase $^{4}$ & Phytase $^{5}$ & Xylanase $^{6}$ & Total score \\
\hline \multicolumn{8}{|c|}{ Proximal Intestine } \\
\hline LRF3A & 4 & 5 & 4 & 5 & 4 & 4 & 26 \\
\hline LRF1X & 2 & 4 & 4 & 3 & 4 & 3 & 20 \\
\hline LRF3X & 4 & 4 & 4 & 4 & 3 & 4 & 23 \\
\hline LR3F3P & 5 & 4 & 4 & 5 & 4 & 5 & 27 \\
\hline \multicolumn{8}{|c|}{ Distal Intestine } \\
\hline LRH2C & 5 & 3 & 3 & 3 & 2 & 4 & 20 \\
\hline LRH3C & 4 & 5 & 4 & 5 & 3 & 4 & 25 \\
\hline LR3H1A & 5 & 5 & 5 & 4 & 4 & 5 & 28 \\
\hline
\end{tabular}

Enzyme activity relates to a pure culture of bacterial isolates; ${ }^{1} \mathrm{O}$ starch (SA) plate; ${ }^{2}$ on gelatin-peptone (GP) plate; ${ }^{3}$ on Tributyrin-agar (TA) plate; ${ }^{4}$ on carboxymethylcellulose (CMC) plate; ${ }^{5}$ on modified phytase screen media (MPSM) plate; ${ }^{6}$ on birchwood xylan plate; $0=$ nil (no halo); 1 = low (6-10 mm halo diameter); $2=$ moderate (11-20 mm halo diameter); $3=$ good (21-30 $\mathrm{mm}$ halo diameter); $4=$ high (31-39 $\mathrm{mm}$ halo diameter); 5 = very high $(\geq 40 \mathrm{~mm}$ halo diameter).

Table 2

Quantitative assay of the enzyme activity (unit activity, $\mathrm{U}$ ) by gut bacteria isolated from the gut of rohu, Labeo rohita

\begin{tabular}{|c|c|c|c|c|c|c|}
\hline Strains & Amylase $[\mathrm{U}]^{1}$ & Protease $[\mathrm{U}]^{2}$ & Lipase $[\mathrm{U}]^{3}$ & Cellulase $[\mathrm{U}]^{4}$ & Phytase $[\mathrm{U}]^{5}$ & Xylanase $[\mathrm{U}]^{6}$ \\
\hline \multicolumn{7}{|c|}{ Proximal Intestine } \\
\hline LRF3A & $261.14 \pm 5.61^{\mathrm{jk}}$ & $81.62 \pm 2.33^{\mathrm{ij}}$ & $4.85 \pm 0.28^{b}$ & $70.42 \pm 2.29^{\mathrm{de}}$ & $225.49 \pm 5.77^{\mathrm{gh}}$ & $10.53 \pm 1.21^{\mathrm{e}}$ \\
\hline LRF1X & $131.49 \pm 3.73^{\mathrm{d}}$ & $67.53 \pm 2.21^{g}$ & $4.56 \pm 0.25^{\mathrm{ab}}$ & $64.49 \pm 2.39^{\mathrm{cd}}$ & $219.57 \pm 5.93^{g}$ & $7.77 \pm 0.45^{\mathrm{d}}$ \\
\hline LRF3X & $253.48 \pm 5.86^{j}$ & $70.40 \pm 2.28^{\mathrm{gh}}$ & $4.77 \pm 0.24^{b}$ & $68.51 \pm 2.30^{\mathrm{d}}$ & $202.65 \pm 5.93^{\mathrm{f}}$ & $10.36 \pm 0.94^{\mathrm{e}}$ \\
\hline LR3F3P & $300.60 \pm 6.04^{\mathrm{m}}$ & $82.38 \pm 2.14^{i}$ & $\begin{array}{l}5.82 \pm 0.23^{\mathrm{c}} \\
\text { Distal Intesti }\end{array}$ & $72.36 \pm 2.34^{\mathrm{de}}$ & $249.51 \pm 6.22^{\mathrm{j}}$ & $15.46 \pm 1.09^{f}$ \\
\hline LRH2C & $271.23 \pm 5.61^{\mathrm{kl}}$ & $49.64 \pm 1.10^{\mathrm{d}}$ & $4.32 \pm 0.23^{\mathrm{ab}}$ & $65.51 \pm 2.48^{\mathrm{cd}}$ & $79.40 \pm 2.28^{c}$ & $9.96 \pm 0.23^{\mathrm{e}}$ \\
\hline LRH3C & $253.46 \pm 5.80^{j}$ & $75.51 \pm 2.42^{\mathrm{hi}}$ & $5.17 \pm 0.29^{b}$ & $71.75 \pm 2.39^{\mathrm{de}}$ & $206.49 \pm 5.89^{f}$ & $10.70 \pm 1.18^{\mathrm{e}}$ \\
\hline LR3H1A & $264.34 \pm 5.03^{\mathrm{jk}}$ & $61.50 \pm 2.17^{\mathrm{f}}$ & $5.93 \pm 0.28^{\mathrm{c}}$ & $72.41 \pm 2.31^{\mathrm{de}}$ & $239.20 \pm 6.18^{\mathrm{i}}$ & $18.68 \pm 1.21^{\mathrm{g}}$ \\
\hline
\end{tabular}

Presented values are means \pm standard error of the mean $(n=3)$; values with the same superscripts in the same column are not significantly different $(P<0.05) ;{ }^{1} \mu$ g maltose liberated $\mathrm{mL}^{-1}$ of enzyme extract $\min ^{-1} ;{ }^{2} \mu \mathrm{g}$ tyrosine liberated $\mathrm{mL}^{-1}$ of enzyme extract $\mathrm{min}^{-1} ;{ }^{3} \mu \mathrm{mole}^{-}$free fatty acid liberated $\mathrm{mL}^{-1}$ of enzyme extract $\min ^{-1} ;{ }^{4} \mu \mathrm{g}$ glucose liberated $\mathrm{mL}^{-1}$ of enzyme extract $\mathrm{min}^{-1} ;{ }^{5} \mu \mathrm{g}$ inorganic phosphate liberated $\mathrm{mL}^{-1}$ of enzyme extract $\min ^{-1} ;{ }^{6} \mathrm{mg}$ D-xylose liberated $\mathrm{mL}^{-1}$ of enzyme extract $\min ^{-1}$.

Table 3

Inhibition zone* produced against different pathogenic bacteria by the potent enzyme-producing bacteria isolated from the gut of rohu, Labeo rohita

\begin{tabular}{lccccc}
\hline \multicolumn{1}{c}{ Strains } & AH & PP & AS & BM & AV \\
\hline LRF3X & - & - & ++ & - & - \\
LR3F3P & +++ & - & +++ & - & ++ \\
LR3H1A & +++ & +++ & - & - & - \\
\hline
\end{tabular}

Inhibition zone produced in double layer method: +, low (6-10 $\mathrm{mm}$ halo diameter); ++, moderate (11-20 mm halo diameter); +++, high (21-25 mm halo diameter); ++++, very high ( $\geq 26 \mathrm{~mm}$ halo diameter); $\mathrm{AH}=$ Aeromonas hydrophila $\mathrm{MTCC} 1739 ; \mathrm{PP}=$ Pseudomonas putida MTCC 1072; AS = Aeromonas salmonicida MTCC 1945; BM = Bacillus mycoides MTCC 7538; AV = Aeromonas veronii KT737240; $\mathrm{PF}=$ Pseudomonas fluorescens $\mathrm{MTCC} 103$. 
produced by both the bacteria remained active following the exposure to a wide range of $\mathrm{pH}$ conditions ( $\mathrm{pH} 3-9)$.

Morphological, physiological, and biochemical characterization of the selected isolates. Both strains were Gram-positive motile rods, catalase positive and capable of utilizing citrate, ribose, xylose, galactose, trehalose, starch, glycogen, etc., but the strains differed in some characteristics. LR3F3P revealed positive result for tryptophan deaminase, indole, and nitrate production. It was capable of utilizing a number of carbon sources and amino acids like mannitol, inositol, sorbitol, arginine, lysine, ornithine, and others. However, LR3H1A could utilize D-melibiose as a carbon source (Table 4).

Genotypic identification of the selected isolates. Based on the nucleotide homology and phylogenetic analysis of the $16 \mathrm{~S}$ rRNA partial gene sequences by nucleotide blast in the NCBI GenBank and RDP databases, the putative probiotic strain LR3H1A was identified as B. subtilis subsp. spizizenii (GenBank accession No. KF623286) showing $99 \%$ similarity to the type strain B. subtilis subsp. spizizenii (AF074970.1). Isolate, LR3F3P showed 99\% similarity with the type strain B. tequilensis (HQ223107.1) and was identified as B. tequilensis (GenBank accession No. KF623287). Phylogenetic relation of the two identified bacterial isolates with other closely related type strains retrieved from the RDP database is presented in the dendrogram (Fig. 3).

Ability to tolerate gastrointestinal condition. The strains, LR3H1A and LR3F3P, grew well in mucus
Table 4

Key biochemical characteristics differentiating strain LR3H1A and LR3F3P

\begin{tabular}{|c|c|c|}
\hline Characteristics & LR3H1A & LR3F3P \\
\hline $\begin{array}{l}\text { Tryptophan } \\
\text { deaminase }\end{array}$ & - & + \\
\hline Indole production & - & + \\
\hline Nitrate reduction & - & + \\
\hline \multicolumn{3}{|l|}{$\begin{array}{l}\text { Carbon source } \\
\text { utilization: }\end{array}$} \\
\hline D-Mannitol & - & + \\
\hline D-Sorbitol & - & + \\
\hline D-Melibiose & + & - \\
\hline D-Arabinose & - & + \\
\hline L-Xylose & - & + \\
\hline Galactose & - & + \\
\hline L-Sorbose & - & + \\
\hline Rhamnose & - & + \\
\hline Lactose & - & + \\
\hline \multicolumn{3}{|l|}{$\begin{array}{l}\text { Amino acid } \\
\text { utilization: }\end{array}$} \\
\hline L-Arginine & - & + \\
\hline L-Lysine & - & + \\
\hline L-Ornithine & - & + \\
\hline
\end{tabular}

LR3H1A = Bacillus subtilis subsp. spizizenii; LR3F3P = Bacillus tequilensis; + positive; - negative.
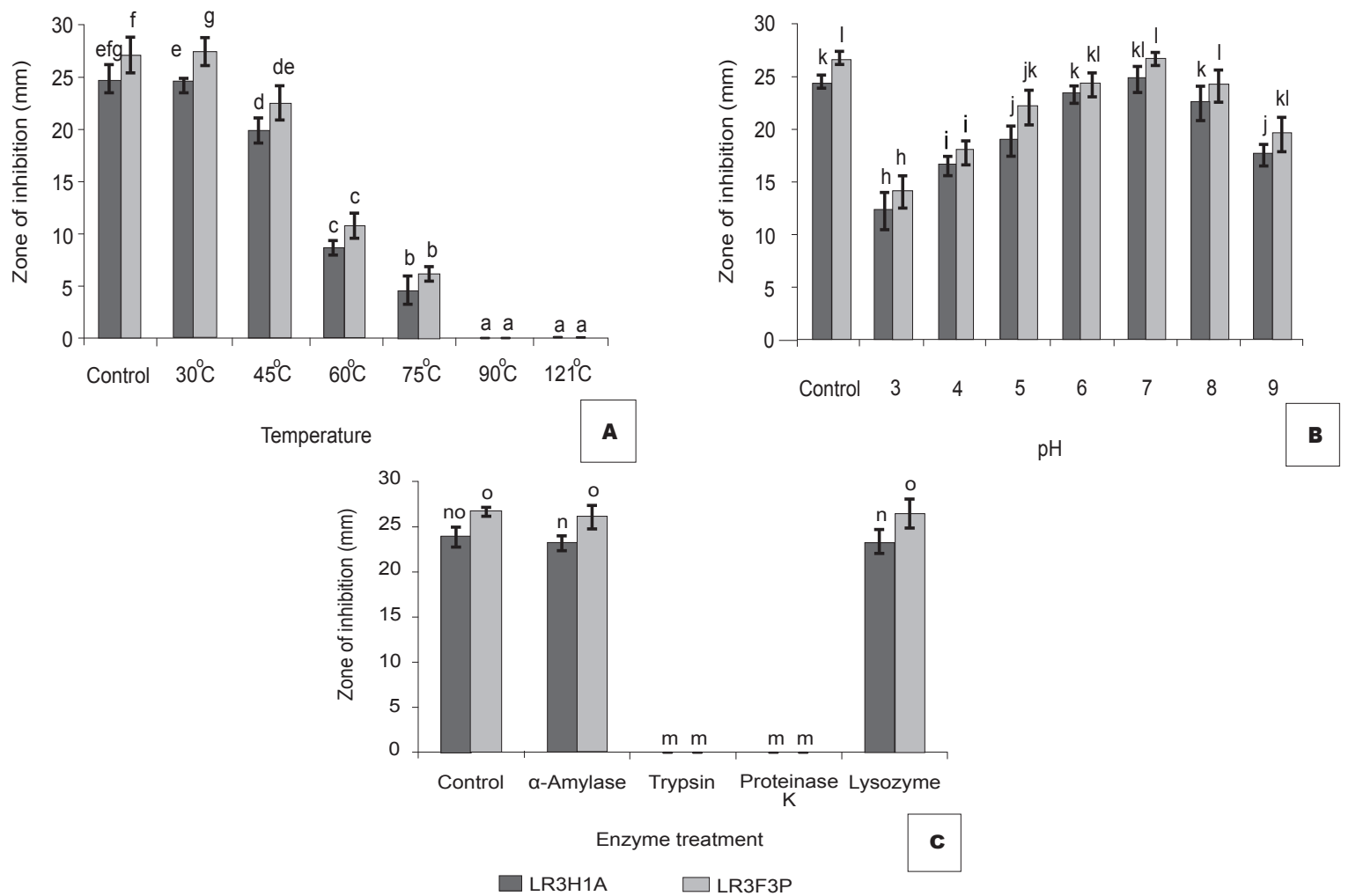

Fig. 2. Effect of $(\mathbf{A})$ temperature $(\mathbf{B}) \mathrm{pH}$, and $(\mathbf{C})$ enzyme treatment on inhibitory activity of cell-free supernatant of Bacillus subtilis subsp. spizizenii LR3H1A and Bacillus tequilensis LR3F3P against Aeromonas hydrophila MTCC1739; data are expressed as mean \pm standard deviation $(n=3), P<0.05$ 
collected from rohu (data not shown) and were capable to withstand diluted bile juice up to a concentration of $11 \%$ and $12 \%$, respectively (data not shown).

Cell surface hydrophobicity assays. Both the isolates (LR3H1A and LR3F3P) showed moderate clumping in spontaneous aggregation assay indicating hydrophobicity of the strains. In the salt aggregation test, LR3H1A and LR3F3P showed clumping at $1 \mathrm{M}$ and $1.25 \mathrm{M}$ ammonium sulphate, respectively. Being eventually lesser than the threshold limit of $2 \mathrm{M}$, both the strains indicated moderate hydrophobic cell surface. The auto-aggregation ability measured over a period of $4 \mathrm{~h}$ exhibited a moderate to strong auto-aggregating attribute of the strains. The ability of auto-aggregation increased with increasing incubation period (Fig. 4a). While comparing auto-aggregation ability $(4 \mathrm{~h})$, strain LR3F3P revealed better autoaggregation ability $(49.33 \pm 1.35 \%)$ than strain LR3H1A $(32.45 \pm 1.43 \%)$. This result could indicate a potential capability of the strains to adhere to epithelial cells and mucosal surfaces. Both bacteria strains were able to coaggregate with the tested pathogens at varied levels (Fig. 4b). Isolate LR3F3P showed the highest co-aggregation percentage with $A$. salmonicida $(36.08 \pm 1.31 \%)$ and the least with $B$. mycoides $(20.37 \pm 1.05 \%)$. On the other hand, isolate LR3H1A illustrated strong co-aggregation with A. hydrophila $(23.75 \pm 1.29 \%)$ but less with P. fluorescens (11.55 $\pm 0.98 \%)$.

Cell surface properties revealed through MATH measurement indicated that both the putative probiotic strains were more of hydrophobic (than hydrophilic) with strong adhesion to xylene, which is an apolar solvent (Fig. 4c). Bacterial adhesion to chloroform and ethyl acetate was evaluated to assess the Lewis acidbase characteristics of cell surfaces. Both the strains showed a stronger affinity towards chloroform, which is an acidic solvent and electron acceptor, than the ethyl acetate, which is a basic solvent and electron donor. Thus, the results might indicate that metabolically the cells are better electron donor and weak electron acceptor.

Ability to form bio-film. Both strains were adherent to polystyrene and glass surfaces following $24 \mathrm{~h}$ of interaction, however, adhesion increased with increasing time of interaction (Fig. 4d).

On a comparative scale, both the strains exhibited a stronger affinity (adherence) towards polystyrene than the glass surface. Further, the strains were noticed to be moderate bio-film producer $\left(0.1<\mathrm{OD}_{570}<1\right)$ in semiquantitative adherence assay (Table 5).

\section{DISCUSSION}

In search of probiotics for fish, isolation followed by a series of consecutive screening process has been suggested to cover both functional and safety aspects (Hai 2015). Since in vivo studies investigating health benefits of potential probiotics are time-consuming and often expensive, the use of in vitro tests as selection criteria is indispensable to reduce the number of strains and, finally to choose the most effective organism. Moreover, an emphasis has also been given on the autochthonous microorganisms to search beneficial bacteria (Fjellheim et al. 2010), as the native flora are supposed to be well adapted to the intended ecological niche (Mukherjee et al. 2016).

Likely use of extracellular enzyme producing bacteria as probiotics has been emphasized in the Indian major carps and other fish species (Ghosh et al. 2002, 2010, Askarian et al. 2012, Ray et al. 2012). Therefore, exogenous enzyme producing ability was considered as the primary criteria for candidate probionts in view

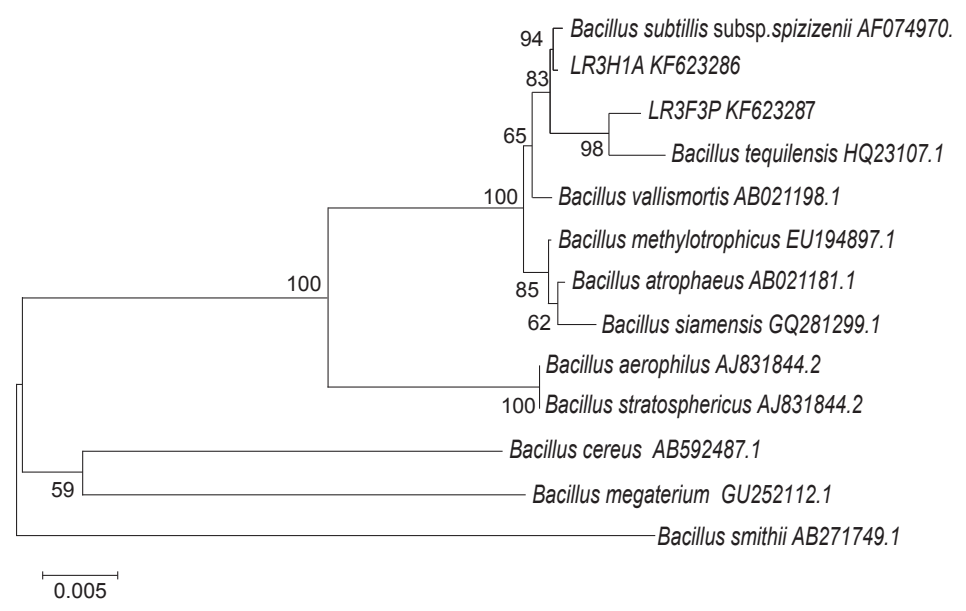

Fig. 3. Dendrogram showing phylogenetic relations of the two potential probiotic bacterial strains, Bacillus subtilis subsp. spizenii LR3H1A (KF623286) and Bacillus tequilensis LR3F3P (KF623287), isolated from rohu, Labeo rohita, with other closely related strains retrieved from NCBI GenBank and RDP; the GenBank accession numbers of the reference strains are shown besides the names; horizontal bars in the dendrogram represent the branch length; similarity and homology of the neighbouring sequences have been shown by bootstrap values; distance matrix was calculated by Kimura- 2 model; the scale bar indicates 0.005 substitutions per nucleotide position; Bacillus smithii AB271749.1 served as an outgroup 
of improved nutrient utilization to support growth. The results of the present study revealed that heterotrophic community within the GI tract of rohu was represented by varied digestive (amylase, protease, lipase) and anti-nutritional factor degrading enzymes (cellulase, phytase, xylanase). Amylolytic, proteolytic, lipolytic, and cellulolytic bacteria occurred almost equally. Although rohu is considered as a phytoplanktophagous fish, the presence of diverse enzyme-producing gut bacteria community might suggest a perfect omnivore feeding habit for rohu (Ghosh et al. 2002). Kar et al. (2008) indicated that the enzyme producing gut bacteria were able to utilize carbohydrates, such as mannose, xylose, raffinose, cellobiose, and cellulose. These substances are mostly detected in plant feedstuffs, and in accordance with this observation gut bacteria might contribute to the digestion in fish (Ray et al. 2012); amylase, cellulase, and xylanase activities by the gut bacteria noticed in the present study might indicate their ability to aid in the digestion of plant feedstuffs in rohu. Furthermore, the metabolic capability of the probiotics to degrade plant-derived anti nutrients is of importance to investigate (Merrifield et al. 2010).

In vitro growth inhibition of pathogens by gut bacteria in fish is a topic that has been less studied in the Indian major carps (Ghosh et al. 2007, Giri et al. 2012, Mukherjee and Ghosh 2016, Nandi et al. 2017). The ability of bacteria strains to inhibit in vitro growth of the pathogenic bacteria has been proposed to be one of the major criteria for selection of probiotics (Kato et al. 2016, Mukherjee et al. 2016). Therefore, antagonism against some fish pathogens was considered as the second criteria for selection of the candidate probionts. In the presently reported study, two strong enzyme producers (LR3H1A and LR3F3P) revealed antagonism against three pathogenic strains and were categorized as strong antagonists. Hence, considering diverse enzyme producing ability and antagonism towards pathogens; isolates LR3H1A and LR3F3P were designated as putative probiotics. Gut bacteria in Indian freshwater fish analysed by culture-dependent methods were mostly represented by Bacillus spp. (Ghosh et al. 2010, Dutta et al. 2015, Mukherjee et al. 2016), which were confirmed by the presently reported study. Being endospore-formers, the members of Bacillus genera are used worldwide as probiotics (Hong et al. 2005), in which Bacillus subtilis is most commonly used in aquaculture. Previously, B. subtilis SG4 isolated from mrigal, Cirrhinus mrigala

Table 5

Semi quantitative estimation of biofilm formation by isolate LR3H1A and LR3F3P

\begin{tabular}{lcc}
\hline \multicolumn{1}{c}{ Strain } & OD $_{570}$ & Inference \\
\hline LR3H1A & $0.260 \pm 0.003$ & Moderate biofilm producer \\
LR3F3P & $0.319 \pm 0.002$ & Moderate biofilm producer \\
\hline
\end{tabular}

LR3H1A = Bacillus subtilis subsp. spizizenii; LR3F3P = Bacillus tequilensis.
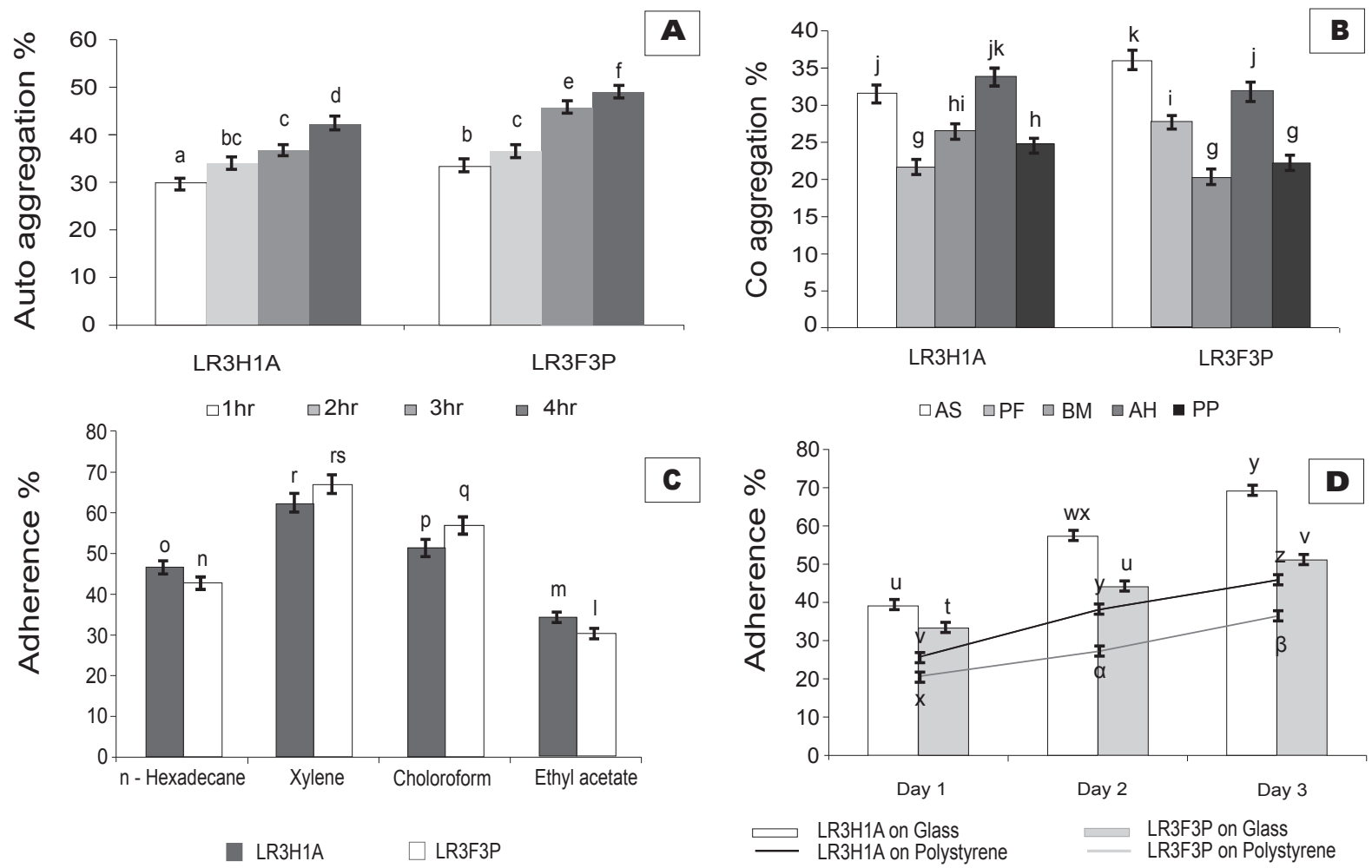

Fig. 4. Cell surface characteristics of Bacillus subtilis subsp. spizizenii LR3H1A and Bacillus tequilensis LR3F3P (A) auto-aggregation percentages measured at 1,2,3, and $4 \mathrm{~h}$ of incubation at room temperature; (B) co-aggregation percentages with pathogens measured at $24 \mathrm{~h}$ of incubation at room temperature; $(\mathbf{C})$ cell surface hydrophobicity (\%) with different solvents after $30 \mathrm{~min}$ of incubation at $30^{\circ} \mathrm{C}$; (D) adherence of the strains on glass and polystyrene surfaces measured at $24 \mathrm{~h}$ interval for 3 days at $30^{\circ} \mathrm{C}$; data are expressed as mean \pm standard deviation $(n=3), P<0.05$ 
(Hamilton 1822), was documented as antagonistic against pathogenic P. Aluorescens, A. hydrophila, and E. tarda (see Ghosh et al. 2007). Probiotic B. subtilis BT23 and diverse Bacillus spp. revealed positive antibacterial activity against pathogenic Vibrio harveyi, both in vitro and in vivo (Vaseeharan and Ramasamy 2003, Janarthanam et al. 2012). Antagonistic activity and other probiotic properties of $B$. infantis KADR2 isolated from the gut of rohu have also been documented (Dharmaraj and Rajendren 2014). Recently $B$. subtilis subsp. spizizenii CC1HG5 and $\mathrm{CC} 2 \mathrm{HG} 7$ were recorded as putative probiotics for catla, Labeo catla (see Mukherjee and Ghosh 2016), while $B$. tequilensis was noticed as probiotics for white leg shrimp, Litopenaeus vannamei (see Luis-Villaseñor et al. 2015). To the author's knowledge, B. tequilensis has not been described as the putative probiotic for finfish.

Extracellular digestive enzyme-producing B. thuringiensis isolated from the GI tract of the Atlantic salmon, Salmo salar Linnaeus, 1758, was shown to inhibit in vitro growth of pathogenic A. salmonicida subsp. salmonicida, Vibrio (Listonella) anguillarum, Moritella viscosa, and Carnobacteriumm altaromaticum (see Askarian et al. 2012). In a study, using Indian major carp, extracellular enzyme-producing B. aerius (KF623288) and $B$. sonorensis (KF623289) showed antagonism against pathogenic $A$. salmonicida, A. hydrophila, and $A$. veronii (see Dutta et al. 2015). Based on these observations, it could be hypothesized from the presently reported investigation that extracellular enzyme-producing bacteria colonizing within the GI tract of rohu might offer protection against some of the fish pathogens.

Bacterial antagonism against other bacteria could be due to either combined or individual production of antibiotics, bacteriocins, lysozymes, proteases, and siderophores (Arora and Verma 2017, Behrens et al. 2017 ), or alteration of $\mathrm{pH}$ with organic acid production (Sugita et al. 1998). In addition, competitive exclusion of the pathogenic bacteria by the probiotic organism has also been hypothesized (Lalloo et al. 2010). The inhibitory activity noticed in the presently reported study cannot be ascribed to the acidity as the extent of antagonism was the highest at the neutralized $\mathrm{pH}$ (7). The cross-streaking and double-layer methods used in the presently reported study may detect the influence of diffusing antimicrobial substances. Moreover, partial characterization of the inhibitory substances suggested that the inhibitory compound was proteinaceous in nature. Additionally, Bacillus spp. are commonly known as key producers of proteinaceous substances (Zokaeifar et al. 2012). In addition to competitive exclusion, results of the presently reported study could indicate secretion of the antibacterial substances by $B$. subtilis subsp. spizizenii and $B$. tequilensis, and the inhibitory compounds could be bacteriocins or bacteriocin-like substances. Similar proteinaceous bacteriocin has been reported from $B$. subtilis (see Xie et al. 2009) and Brevibacillus borstelensis (see Sharma et al. 2014). In addition, optimum temperature $\left(30^{\circ} \mathrm{C}\right)$ and $\mathrm{pH}(7)$ for antibacterial activity obtained in the presently reported study was in accordance with previous studies (Ghanbari et al. 2009, Xie et al. 2009). Though, it is apparent that antagonism due to such compounds is highly dependent on the experimental conditions that might differ in vitro and in vivo (Verschuere et al. 2000).

A probiotic bacterium should have the capacity to tolerate fish GI conditions. Therefore, growth in fish mucus and tolerance to fish bile juice were considered as criteria to assure viability of the candidate probionts within fish GI tract. Both the selected gut bacteria, LR3H1A and LR3F3P, grew well in fish mucus and were noticed to tolerate diluted fish bile juice $(11 \%$ and $12 \%$, respectively), which indicate their ability to withstand GI condition. Similar observations were recorded in earlier works on mrigal (Dutta and Ghosh 2015) and catla (Dutta et al. 2015). Safety of the host is another prerequisite for any probiotic bacterium (Verschuere et al. 2000). In the presently reported study, intra-peritoneal injection of the selected isolates did not induce any pathological signs or mortalities in rohu during the short term in vivo trial and thus could be considered as safe for the targeted fish species.

Aggregation between microorganisms of the same strain (auto-aggregation) or between different strains (co-aggregation) is of considerable importance in several ecological niches (Jena et al. 2013). Bacterial cell surface hydrophobicity and auto-aggregation capacity are directly correlated and hydrophobicity could be considered as one of the determinants of auto-aggregation (Patel et al. 2009). In the presently reported study, cells of both the putative probionts adhered strongly to xylene demonstrating hydrophobic cell surface of the strains. On the other hand, both $B$. subtilis subsp. spizizenii LR3H1 A and B. tequilensis LR3F3P represented moderate to strong auto-aggregation ability. Moreover, the strains were washed in sterile PBS that will exclude the possibility of auto-aggregation due to extracellular components as elucidated by Kos et al. (2003). The aggregating probiotic bacteria may achieve adequate colonization to adhere to gut mucosal surfaces of the host or form bio-film (water additive) as described elsewhere (Grześkowiak et al. 2012, Jena et al. 2013). The capacity of $B$. subtilis subsp. spizizenii LR3H1A and B. tequilensis LR3F3P to co-aggregate with potential gut pathogens might enable them to form a barrier that would prevent colonization of pathogenic bacteria within GI tract (Dias et al. 2013).

\section{CONCLUSIONS AND FUTURE PERSPECTIVES}

It has become evident that the selected bacteria may function to improve the nutrient utilization (through enzymatic potential) and prevent pathogens to adhere to and colonize the GI tract. In spite of representing cell surface hydrophobicity, both the putative probiotics depicted moderate bio-film-producing ability through semi-quantitative adherence assay. Therefore, we suggest that the application of the putative probiotics characterized in the presently reported study as feed additive could be more consequential than as water additive. As gut bacteria might also be loosely associated with mucus layer (Johansson et al. 2008), mucus associated 
microbiota merits further investigation for screening of beneficial bacteria (Ringø et al. 2016). Although in vitro characterization of the probiotic properties could be indicative of functionality, viability and colonization potential of the putative probiotics, assumptions based on in vitro experiments might not comply exactly with in vivo conditions. Therefore, in vivo studies should be carried out using the autochthonous strains isolated in the presently reported study, and subsequent studies should involve challenge studies and the effect on immune parameters. Furthermore, culture-independent methodologies should be employed in order to describe the effects of probiotics and other biotic or abiotic factors on the gut microbial communities across temporal and spatial scale as suggested by Ringø et al. (2016).

\section{ACKNOWLEDGEMENTS}

Sincere thanks to the Head, Department of Zoology, The University of Burdwan, West Bengal, India; The Department of Science and Technology (FIST and PURSE programmes), New Delhi, India and The University Grants Commission (UGC-SAP-DRS programme), New Delhi, India for providing research facilities. The first author (DD) is grateful to The Council of Scientific and Industrial Research (CSIR), New Delhi, India for awarding the Junior Research Fellowship.

\section{REFERENCES}

Alippi A.M., Reynaldi F.J. 2006. Inhibition of the growth of Paenibacillus larvae, the causal agent of American foulbrood of honeybees, by selected strains of aerobic spore-forming bacteria isolated from apiarian sources. Journal of Invertebrate Pathology 91 (3): 141-146. DOI: 10.1016/j.jip.2005.12.002

Anonymous 2018. FAO yearbook. Fishery and Aquaculture Statistics 2016/FAO annuaire. Statistiques des pêches et de l'aquaculture 2016/FAO anuario. Estadísticas de pesca y acuicultura 2016. FAO, Rome.

Arora N.K., Verma M. 2017. Modified microplate method for rapid and efficient estimation of siderophore produced by bacteria. 3 Biotech 7: e381. DOI: 10.1007/s13205-017-1008-y

Askarian F., Zhou Z., Olsen R.E., Sperstad S., Ringø E. 2012. Culturable autochthonous gut bacteria in Atlantic salmon (Salmo salar L.) fed diets with or without chitin. Characterization by $16 \mathrm{~S}$ rRNA gene sequencing, ability to produce enzymes and in vitro growth inhibition of four fish pathogens. Aquaculture 326-329: 1-8. DOI: 10.1016/j.aquaculture.2011.10.016

Bailey M.J., Biely P., Poutanen K. 1992. Interlaboratory testing of methods for assay of xylanase activity. Journal of Biotechnology 23 (3): 257-270. DOI: 10.1016/0168-1656(92)90074-J

Behrens H.M., Six A., Walker D., Kleanthous C. 2017. The therapeutic potential of bacteriocins as protein antibiotics. Emerging Topics in Life Sciences 1 (1): 65-74. DOI: 10.1042/ETLS20160016
Bergey D.H., Holt J.G. 1994. Bergey's manual of determinative bacteriology. 9th edn. Williams and Wilkins, Baltimore, MD, USA.

Bernfeld P. 1955. Amylases, alpha and beta. Pp. 149-158. In: Colowick S.P., Kaplan N.O. (eds.) Methods in enzymology. Volume 1. Academic Press, New York, NY, USA.

Bier M. 1955. Lipases. Pp. 627-642. In: Colowick S.P., Kaplan N.O. (eds.) Methods in enzymology. Volume 1. Academic Press, New York, NY, USA.

Burr G., Gatlin D.III, Ricke S. 2005. Microbial ecology of the gastrointestinal tract of fish and the potential application of prebiotics and probiotics in finfish aquaculture. Journal of the World Aquaculture Society 36 (4) 425-436. DOI: 10.1111/j.1749-7345.2005. tb00390.x

Chaieb K., Chehab O., Zmantar T., Rouabhia M., Mahdouani K., Bakhrouf A. 2007. In vitro effect of $\mathrm{pH}$ and ethanol on biofilm formation by clinical icapositive Staphylococcus epidermidis strains. Annals of Microbiology 57 (3): 431-437. DOI: 10.1007/ BF03175085

Cruz P.M., Ibánez A.L. Hermosillo O.A.M., Saad H.C.R. 2012. Use of probiotics in aquaculture. ISRN Microbiology 2012: e916845. DOI: 10.5402/2012/916845

Das P., Mandal S., Khan A., Manna S.K., Ghosh K. 2014. Distribution of extracellular enzyme-producing bacteria in the digestive tracts of 4 brackish water fish species. Turkish Journal of Zoology 38 (1): 79-88. DOI: 10.3906/zoo-1205-3

Del Re B., Sgorbati B., Miglioli M., Palenzona D. 2000. Adhesion, autoaggregation and hydrophobicity of 13 strains of Bifidobacterium longum. Letters in Applied Microbiology 31 (6): 438-442. DOI: 10.1046/j.13652672.2000.00845.x

Denev S., Staykov Y., Moutafchieva R., Beev G. 2009. Microbial ecology of the gastrointestinal tract of fish and the potential application of probiotics and prebiotics in finfish aquaculture. International Aquatic Research 1 (1): 1-29.

Denison D.A., Koehn R.D. 1977. Cellulase activity of Poronia oedipus. Mycologia 69 (3): 592-601. DOI: $10.2307 / 3758562$

Dharmaraj R., Rajendren V. 2014. Probiotic assessment of Bacillus infantis isolated from gastrointestinal tract of Labeo rohita. International Journal of Scientific and Research Publications 4 (7): 1-6.

Dias F.S., Duarte W.F., Schwan R.F. 2013. Evaluation of adhesive properties of presumptive probiotic Lactobacillus plantarum strains. Bioscience Journal 29 (5): 1678-1686.

Dopazo C., Lemos M., Lodeiros C., Bolinches J., Barja J., Toranzo A. 1988. Inhibitory activity of antibioticproducing marine bacteria against fish pathogens. Journal of Applied Bacteriology 65 (2): 97-101. DOI: 10.1111/j.1365-2672.1988.tb01497.x 
Dutta D., Banerjee S., Mukherjee A., Ghosh K. 2015. Selection and probiotic characterization of exoenzymeproducing bacteria isolated from the gut of Catla catla (Actinopterygii: Cypriniformes: Cyprinidae). Acta Ichthyologica et Piscatoria 45 (4): 373-384. DOI: 10.3750/AIP2015.45.4.05

Dutta D., Ghosh K. 2015. Screening of extracellular enzyme-producing and pathogen inhibitory gut bacteria as putative probiotics in mrigal, Cirrhinus mrigala (Hamilton, 1822). International Journal of Fisheries and Aquatic Studies 2 (4): 310-318.

Fjellheim A.J., Klinkenberg G., Skjermo J., Aasen I.M., Vadstein O. 2010. Selection of candidate probionts by two different screening strategies from Atlantic cod (Gadus morhua L.) larvae. Veterinary Microbiology 144 (1-2): 153-159. DOI: 10.1016/j. vetmic.2009.12.032

Ghanbari M., Rezaei M., Jami M., Nazari R.M. 2009. Isolation and characterization of Lactobacillus species from intestinal contents of beluga (Huso huso) and Persian sturgeon (Acipenser persicus). Iranian Journal of Veterinary Research 10 (2): 152-157.

Ghosh K., Roy M., Kar N., Ringø E. 2010. Gastrointestinal bacteria in rohu, Labeo rohita (Actinopterygii: Cypriniformes: Cyprinidae): Scanning electron microscopy and bacteriological study. Acta Ichthyologica et Piscatoria 40 (2): 129135. DOI: 10.3750/AIP2010.40.2.05

Ghosh K., Sen S.K., Ray A.K. 2002. Characterization of bacilli isolated from gut of rohu, Labeo rohita, fingerlings and its significance in digestion. Journal of Applied Aquaculture 12 (3): 33-42. DOI: 10.1300/ J028v12n03_04

Ghosh S., Sinhä A., Sahu C. 2007. Isolation of putative probionts from the intestines of Indian major carps. Israeli Journal of Aquaculture - Bamidgeh 59 (3): 127-132.

Giri S.S., Sen S.S., Sukumaran V. 2012. Effects of dietary supplementation of potential probiotic Pseudomonas aeruginosa VSG-2 on the innate immunity and disease resistance of tropical freshwater fish, Labeo rohita. Fish and Shellfish Immunology 32 (6): 1135-1140. DOI: $10.1016 /$ j.fsi.2012.03.019

Gray C.D., Kinnear P.R. 2011. IBM SPSS Statistics 19 made simple. Psychology Press, Hove, East Sussex, UK.

Grześkowiak L., Collado M.C., Salminen S. 2012. Evaluation of aggregation abilities between commensal fish bacteria and pathogens. Aquaculture 356-357: 412-414. DOI: 10.1016/j.aquaculture.2012.04.015

Gupta A., Gupta P., Dhawan A. 2016. Paenibacillus polymyxa as a water additive improved immune response of Cyprinus carpio and disease resistance against Aeromonas hydrophila. Aquaculture Reports 4: 86-92. DOI: 10.1016/j.aqrep.2016.07.002

Hai N.V. 2015. The use of probiotics in aquaculture. Journal of Applied Microbiology 119 (4): 917-935. DOI: $10.1111 /$ jam.12886
Hong H.A., Duc L.H., Cutting S.M. 2005. The use of bacterial spore formers as probiotics. FEMS Microbiology Reviews 29 (4): 813-835. DOI: 10.1016/j.femsre.2004.12.001

Howson S.J., Davis R.P. 1983. Production of phytatehydrolysing enzyme by some fungi. Enzyme and Microbial Technology 5 (5): 377-382. DOI: 10.1016/0141-0229(83)90012-1

Jacobs M.B., Gerstein M.J. 1960. Handbook of microbiology. Van Nostrand, Princeton, NJ, USA.

Janarthanam K., George M.R., John K.R., Jeyaseelan M.J.P. 2012. In vitro and in vivo biocontrol of Vibrio harveyi using indigenous bacterium Bacillus spp. Indian Journal of Geo-Marine Sciences 41 (1): 83-89.

Jena P.K., Trivedi D., Thakore K., Chaudhary H., Giri S.S., Seshadri S. 2013. Isolation and characterization of probiotic properties of lactobacilli isolated from rat fecal microbiota. Microbiology and Immunology 57 (6): 407-416. DOI: 10.1111/1348-0421.12054

Johansson M.E.V., Phillipson M., Petersson J., Velcich A., Holm L., Hansson G.C. 2008. The inner of the two Muc2 mucin-dependent mucus layers in colon is devoid of bacteria. Proceedings of the National Academy of Sciences of the United States of America 105 (39): 15064-15069. DOI: 10.1073/pnas.0803124105

Kar N., Roy R.N., Sen S.K., Ghosh K. 2008. Isolation and characterization of extracellular enzyme producing bacilli in the digestive tracts of rohu, Labeo rohita (Hamilton) and murrel, Channa punctatus (Bloch). Asian Fisheries Science 21: 421-434.

Kato C.D., Kabarozi R., Majalija S., Tamale A., Musisi N.L., Sengooba A. 2016. Isolation and identification of potential probiotic bacteria on surfaces of Oreochromis niloticus and Clarias gariepinus from around Kampala, Uganda. African Journal of Microbiology Research 10 (36): 1524-1530. DOI: 10.5897/AJMR2016.8235

Kesarcodi-Watson A., Kaspar H., Lategan M.J., Gibson L. 2008. Probiotics in aquaculture: The need, principles and mechanisms of action and screening processes. Aquaculture 274 (1): 1-14. DOI: 10.1016/j. aquaculture.2007.11.019

Kimoto H., Kurisaki J., Tsuji T.M., Ohmomo S., Okamoto T. 1999. Lactococci as probiotic strains: Adhesion to human enterocyte-like Caco-2 cells and tolerance to low $\mathrm{pH}$ and bile. Letters in Applied Microbiology 29 (5): 313-316. DOI: 10.1046/j.13652672.1999.00627.x

Klayraung S., Viernstein H., Sirithunyalug J., Okonogi S. 2008. Probiotic properties of lactobacilli isolated from Thai traditional food. Scientia Pharmaceutica 76 (3): 485-503. DOI: 10.3797/scipharm.0806-11

Kos B., Šušković J., Vuković S., Šimpraga M., Frece J., Matošić S. 2003. Adhesion and aggregation ability of probiotic strain Lactobacillus acidophilus M92. Journal of Applied Microbiology 94 (6): 981-987. DOI: 10.1046/j.1365-2672.2003.01915.X

Krepsky N., Ferreira R.B.R., Nunes A.P.F., Lins U.G.C., Filho F.C.S., Mattos-Guaraldi A.L. Netto- 
dosSantos K.R. 2003. Cell surface hydrophobicity and slime production of Staphylococcus epidermidis Brazilian isolates. Current Microbiology 46 (4): 280 286. DOI: $10.1007 / \mathrm{s} 00284-002-3868-5$

Lalloo R., Moonsamy G., Ramchuran S., Görgens J., Gardiner N. 2010. Competitive exclusion as a mode of action of a novel Bacillus cereus aquaculture biological agent. Letters in Applied Microbiology 50 (6): 563570. DOI: $10.1111 / \mathrm{j} .1472-765 x .2010 .02829 . x$

Lane D.J. 1991. 16S/23S rRNA sequencing. Pp. 115-175. In: Stackebrandt E., Goodfellow M. (eds.) Nucleic acid techniques in bacterial systematics. John Wiley and Sons, Chichester, New York, Brisbane, Toronto, Singapore.

Li X., Ringø E., Hoseinifar S.H., Lauzon H.L., Birkbeck H., Yang D. 2018. The adherence and colonization of microorganisms in fish gastrointestinal tract. Reviews in Aquaculture [Early View.] DOI: 10.1111/raq.12248

Liu H., Guo X., Gooneratne R., Lai R., Zeng C., Zhan F., Wang W. 2016. The gut microbiome and degradation enzyme activity of wild freshwater fishes influenced by their trophic levels. Scientific Reports 6: e24340. DOI: $10.1038 /$ srep24340

Luis-Villaseñor I.E., Voltolina D., Gomez-Gil B., Ascencio F., Campa-Córdova Á.I., Audelo-Naranjo J.M., Zamudio-Armenta O.O. 2015. Probiotic modulation of the gut bacterial community of juvenile Litopenaeus vannamei challenged with Vibrio parahaemolyticus CAIM 170. Latin American Journal of Aquatic Research 43 (4): 766-775. DOI: 10.3856/ vol43-issue4-fulltext-15

Mandal S., Ghosh K. 2013. Isolation of tannase-producing microbiota from the gastrointestinal tracts of some freshwater fish. Journal of Applied Ichthyology 29 (1): 145-153. DOI: 10.1111/j.1439-0426.2012.02054.x

Mattos-Guaraldi A.L., Formiga L.C.D., Andrade A.F.B. 1999. Cell surface hydrophobicity of sucrose fermenting and non fermenting Corynebacterium diphtheriae strains evaluated by different methods. Current Microbiology 38 (1): 37-42. DOI: 10.1007/ PL00006769

Merrifield D.L., Dimitroglou A., Foey A., Davies S.J., Baker R.T.M., Bøgwald J., Castex M., Ringø E. 2010. The current status and future focus of probiotic and prebiotic applications for salmonids. Aquaculture $\mathbf{3 0 2}$ (1-2): 1-18. DOI: 10.1016/j.aquaculture.2010.02.007

Mukherjee A., Dutta D., Banerjee S., Ringø E., Breines E.M., Hareide E., Chandra G., Ghosh K. 2016. Potential probiotics from Indian major carp, Cirrhinus mrigala. Characterization, pathogen inhibitory activity, partial characterization of bacteriocin and production of exoenzymes. Research in Veterinary Science 108: 76-84. DOI: 10.1016/j.rvsc.2016.08.011

Mukherjee A., Ghosh K. 2016. Antagonism against fish pathogens by cellular components and verification of probiotic properties in autochthonous bacteria isolated from the gut of an Indian major carp, Catla catla (Hamilton). Aquaculture Research 47 (7): 2243-2255. DOI: $10.1111 /$ are. 12676
Nandi A., Dan S.K., Banerjee G., Ghosh P., Ghosh K., Ringø E., Ray A.K. 2017. Probiotic potential of autochthonous bacteria isolated from the gastrointestinal tract of four freshwater teleosts. Probiotics and Antimicrobial Proteins 9 (1): 12-21. DOI: $10.1007 / \mathrm{s} 12602-016-9228-8$

Ninawe S., Lal R., Kuhad R.C. 2006. Isolation of three xylanase-producing strains of Actinomycetes and their identification using molecular methods. Current Microbiology 53 (3): 178-182. DOI: 10.1007/s00284005-0285-6

Patel A.K., Ahire J.J., Pawar S.P., Chaudhari B.L., Chincholkar S.B. 2009. Comparative accounts of probiotic characteristics of Bacillus spp. isolated from food wastes. Food Research International 42 (4): 505510. DOI: 10.1016/j.foodres.2009.01.013

Ray A.K., Ghosh K., Ringø E. 2012. Enzyme-producing bacteria isolated from fish gut: A review. Aquaculture Nutrition 18 (5): 465-492. DOI: 10.1111/j.13652095.2012.00943.x

Ringø E., Zhou Z., Vecino J.L.G., Wadsworth S., Romero J., Krogdahl Å., Olsen R.E., Dimtroglou A., Foey A., Davies S., Owen M., Lauzon H.L., Martinsen L.L., De Schryver P., Bossier P., Sperstad S., Merrifield D.L. 2016. Effect of dietary components on the gut microbiota of aquatic animals. A never-ending story? Aquaculture Nutrition 22 (2): 219-282. DOI: 10.1111/anu.12346

Romero J., Ringø E., Merrifield D.L. 2014. The gut microbiota of fish. Pp. 75-100. DOI: 10.1002/9781118897263.ch4 In: Merrifield D.L., Ringø E. (eds.) Aquaculture Nutrition: Gut Health, Probiotics and Prebiotics. John Wiley and Sons, Ltd, New Jersey, USA. DOI: 10.1002/9781118897263

Sangiliyandi G., Gunasekaran P. 1996. Extracellular lipase producing Bacillus licheniformis from an oil mill refinery effluent. Indian Journal of Microbiology 36: 109-110.

Sharma N., Gupta A., Gautam N. 2014. Characterization of bacteriocin like inhibitory substance produced by a new strain Brevibacillus borstelensis AG1 isolated from 'Marcha'. Brazilian Journal of Microbiology 45 (3): 1007-1015. DOI: 10.1590/S151783822014000300033

Sugita H., Hirose Y., Matsuo N., Deguchi Y. 1998. Production of the antibacterial substance by Bacillus sp. strain NM12, an intestinal bacterium of Japanese coastal fish. Aquaculture 165 (3-4): 269-280. DOI: 10.1016/s0044-8486(98)00267-1

Sugita H., Mizuki H., Itoi S. 2012. Diversity of siderophore-producing bacteria isolated from the intestinal tracts of fish along the Japanese coast. Aquaculture Research 43 (4): 481-488. DOI: 10.1111/j.1365-2109.2011.02851.x

Tang K.L., Caffrey N.P., Nóbrega D.B., Cork S.C., Ronksley P.E., Barkema H.W., Polachek A.J., Ganshorn H., Sharma N., Kellner J.D., Ghali W.A. 2017. Restricting the use of antibiotics in foodproducing animals and its associations with antibiotic 
resistance in food-producing animals and human beings: A systematic review and meta-analysis. The Lancet Planetary Health 1 (8): e316-e327. DOI: 10.1016/S2542-5196(17)30141-9

Teather R.M., Wood P.J. 1982. Use of Congo redpolysaccharide interactions in enumeration and characterization of cellulolytic bacteria from the bovine rumen. Applied and Environmental Microbiology 43 (4): 777-780.

Vaseeharan B., Ramasamy P. 2003. Control of pathogenic Vibrio spp. by Bacillus subtilis BT23, a possible probiotic treatment for black tiger shrimp Penaeus monodon. Letters in Applied Microbiology 36 (2): 83-87. DOI: 10.1046/j.1472-765X.2003.01255.x

Verschuere L., Rombaut G., Sorgeloos P., Verstraete W. 2000. Probiotic bacteria as biological control agents in aquaculture. Microbiology and Molecular Biology Reviews 64 (4): 655-671. DOI: 10.1128/ mmbr.64.4.655-671.2000

Walter H.E. 1984. Proteinases: Methods with hemoglobin, casein and azocoll as substrates. Pp. 270-277. In: Bergmeyer H.-U. Methods of enzymatic analysis. Volume 5. Verlag Chemie, Weinheim, Germany.

Wang A.R., Ran C., Ringø E., Zhou Z.G. 2018. Progress in fish gastrointestinal microbiota research. Reviews in Aquaculture 10 (3): 626-640. DOI: 10.1111/raq.12191
Xie J.H., Zhang R.J., Shang C.J., Guo Y.Q. 2009. Isolation and characterization of a bacteriocin produced by an isolated Bacillus subtilis LFB112 that exhibits antimicrobial activity against domestic animal pathogens. African Journal of Biotechnology 8 (20): 5611-5619.

Yaghobi M., Heyrati F.P., Akhlaghi M., Dorafshan S., Mahmoudi N. 2014. Intestinal microbiota of striped catfish, Pangasianodon hypophthalmus (Sauvage, 1878) fed on dietary nucleotide. Iranian Journal of Ichthyology 1 (4): 274-280.

Yanke L.J., Selinger L.B., Cheng K.-J. 1999. Phytase activity of Selenomonas ruminantium: A preliminary characterization. Letters in Applied Microbiology 29 (1): 20-25. DOI: 10.1046/j.1365-2672.1999.00568.x

Zar J.H. 2010. Biostatistical Analysis. Pearson Education, Delhi, India.

Zokaeifar H., Balcázar J.L., Saad C.R., Kamarudin M.S., Sijam K., Arshad A., Nejat N. 2012. Effects of Bacillus subtilis on the growth performance, digestive enzymes, immune gene expression and disease resistance of white shrimp, Litopenaeus vannamei. Fish and Shellfish Immunology 33 (4): 683-689. DOI: 10.1016/j.fsi.2012.05.027

Received: 26 May 2017

Accepted: 7 August 2018

Published electronically: 30 September 2018 